\title{
Library Service to Technical Agriculturists ${ }^{1}$
}

\section{Miss Bercaw is assistant librarian, U.S. Department of Agriculture Library.}

$I^{\prime}$ A paper before the Agricultural $\mathrm{Li}$ braries Section in May 1929, Claribel R. Barnett paraphrased Dr. George Watson Cole's definition of the "ideally perfect library," as follows: "... the ideally perfect agricultural library would contain all the books ever printed on agriculture and the related sciences from the first book on agriculture by Crescentius published in I $47 \mathrm{I}$ down to the latest books and bulletins of the present day." Unfortunately, or perhaps fortunately-since there is a space problem involved-such a library exists only in the imagination today, as Miss Barnett pointed out that it did in 1929 .

Good library service to technical agricultural workers is not dependent on a library's containing all the books ever printed on agriculture and the related sciences, but on its containing the publications most likely to be needed by its clientele, on its access to all other publications wherever they may be found, and on the skill and promptness with which its personnel make the contents of the books available to the worker.

To give such service, a library should have a discriminating acquisition policy, a competent, well-trained staff, a suitable and comfortable plant to house and care for its books and workers, and adequate funds for its operation.

1 Paper presented at meeting of Agricultural Libraries Section, A.C.R.L., June 18, 1948, Atlantic City, N.J.
A library's acquisition policy is governed, of course, by its needs and by the size of its book fund, and by the number of publications it can obtain as gifts or through exchange. It seems unnecessary for all agricultural libraries to atempt to acquire and maintain, even if they could, complete collections in the field of agriculture. Collections sufficient for ordinary needs may be supplemented by interlibrary loans from the U.S.D.A. Library, the Library of Congress, and other large or more specialized libraries.

Much has been written on the qualifications of a technical library staff and on whether the librarian and his professional assistants should be professional librarians or subject specialists, or both. No attempt will be made here to add further to the discussion, except to say that the more knowledge our professional staffs have of agriculture, the underlying sciences, and foreign languages the better equipped they will be to give efficient service. Although the library that I represent does not require, except in certain of our higher grade positions, that our employees have some knowledge of one or more of the underlying sciences in the field of agriculture, we are always on the alert for persons with special subject or language qualifications, whatever their grade. The first requisite, of course, is that they have a good education and library training, or library experience, in the work which they are to perform, whether it be cataloging, acquisition, refer- 
ence, or bibliography. In-service training in subject specialties may be acquired on the job or from courses given by the department's graduate school or by universities in Washington.

It is, perhaps, unnecessary to elaborate on the statement that a library should have adequate funds for its operation. On the adequacy of such funds depends, to a great extent, the success of the library in giving efficient, prompt service. Increasing demands for service without a corresponding increase in funds to employ additional staff to meet such demands, is a problem which many libraries have to face.

Ralph $\mathrm{R}$. Shaw, in an article in the $W$ ilson Library Bulletin for January 1947 , stated: "There are only two ways to meet increasing service demands. One is to get more money. The other is to do all the work that can be done by applying the principles of scientific management to effect most efficient utilization of the money and manpower already at your disposal." The first suggestion may be impossible; nothing should stand in the way of the second.

Granted that the library has reasonably adequate funds, an adequate book collection, and a well-trained and competent staff, what services should the technical agricultural worker expect the library to provide for him and how should they be given?

First, the service should be prompt, courteous, and efficient. The last two may be taken for granted. Promptness of service should be emphasized. Users have a right to expect a minimum of delay in filling a request for a book or in answering a reference question. Too frequent, or too long delays should be investigated at once. We may find that the fault lies not in a lack of sufficient personnel to do the job, but in a lack of supervision or inefficient methods of handling requests. Perhaps we are concentrating so hard on doing the job that we neglect to question how we are doing it. Time studies and quality checks pay dividends in even the smallest library.

Second, service should be given with imagination, sympathy, and interest. These qualities are implied, of course, in efficient service, but seem to need special emphasis.

Third, the service should be for all the workers, actual and potential, of the university, college, institution, or government agency which the library is set up to serve. This means telephone and messenger service for those whose offices are not close to the library; and mail service and branch libraries or station collections for those at even greater distances.

No matter where he is assigned by his agency, the research worker is entitled to, and should expect, library service. Indeed, the library should provide the individual research worker, or group of workers, who may be located a thousand miles or so from their agency's headquarters, with such good mail service that the absence of a library would scarcely be felt.

Fourth, since the library should serve all the workers, the service should include some means of acquainting them with what the library has to offer. The library, in turn, should become acquainted with its agency's research programs and with the workers' needs in order to anticipate and meet their needs as well as their demands.

The fifth is a service which every user expects to find, and does find in his librarya service which most of us criticize occasionally, but which provides the main key to the library's resources and probably is used more frequently than any other library tool. This is the card catalog. Cataloging is expensive, especially the full cataloging which most of us were taught in library school and which most reference librarians think they need. Simplified cataloging, which is being practiced increasingly by li- 
braries, even the Library of Congress, may be the answer to the cost problem. If we are careful to retain the essentials in brief cataloging, the users of our catalogs may not miss the details which they formerly considered necessary. It is even conceivable that some technical agricultural workers may find the cards easier to understand.

Cutting down on the number of analytics is another way to reduce cataloging costs. Why should we attempt the impossible and try to include many analytics in our card catalogs, when published indexes and bibliographies make so many more of them available to us.

Sixth, the library should provide a liberal loan service, with renewal privileges. As has been indicated, this service should be prompt. Periodical routing should be provided for those who need to keep up with current articles in their fields of interest. If this service is to be effective, multiple copies will be needed to supply the demand. A browsing collection of the most soughtafter periodicals, maintained concurrently with the routing service, will help prevent too great an expansion of that service.

Seventh, the technical agricultural worker should be given as much efficient and prompt reference and bibliographical service as he needs and as the library can give him. How to do this with a small library staff and inadequate funds will be one of the library's major problems. It is not suggested that each library organize its reference services as does the U.S.D.A. Library which divides them into three categories: (I) Telephone Reference, which handles such questions as may be answered from the card catalog, the $U . S$. Catalog, the Union List of Serials, and similar aids, (2) Reference, which handles questions that take up to thirty minutes to answer; and (3) Bibliography, which does extensive searching. Both Reference and Bibliog- raphy frequently answer very "quick" reference questions which, in many instances are so classified only because the person answering them quickly has had long experience on the job or because of special knowledge of the literature. Occasionally, when it is expedient to do so, Reference does extended searching, but in general the plan is as described. The prompt and intelligent handling of all requests, both simple and complex, should be the aim of the reference department. Literature searching and compiling subject bibliographies, indexes and card catalogs are not luxuries but the backbone of library service, and should be provided.

In addition to literature searching and compiling bibliographies-or perhaps even before that-the worker needs to be informed of what is being published currently in his subject field. This may be accomplished through the routing of periodicals, mentioned earlier, and through news letters and accession lists prepared by the library.

Another answer to the problem is the generous provision of published index and abstract journals such as Biological $A b$ stracts, Chemical Abstracts, Index Veterinarius, Horticultural Abstracts, Review of Applied Entomology, Agricultural Index, $N u t r i t i o n$ Abstracts, Index-Catalogue of the Library of the Surgeon General's Office, Current List of Medical Literature, and the Bibliography of Agriculture. The monthly Bibliography of Agriculture, first published in its present form in July I943, is designed to list all the current publications in the field of agriculture as they are received in the United States Department of Agriculture Library. The classified arrangement which is followed enables the reader to learn what has been published in his fieldbe it virus diseases of plants, soil chemistry, veterinary medicine, Lepidoptera, prices of agricultural products, or land tenure. 
Author and subject indexes aid both the librarian and the reader in finding what a specific author has written, or all that has been published on a specific subject. Checklists of the publications of the United States Department of Agriculture, state agricultural experiment stations, and the state agricultural extension services-which follow the classified sections-are the most complete checklists of the current publications for those agencies.

A service most appreciated by technical workers is the photographic reproduction of library materials, in lieu of the loan of the original publication. It is interesting to note in the I9Io report of the United States Department of Agriculture Library the following prediction:

When some cheap and simple method of exact reproduction is perfected, the problems connected with the interlibrary loans will be greatly reduced. It will then be feasible, when only parts of volumes are needed, to make copies of the articles to send out of the city instead of sending the volumes.

H. J. Webber, in a paper before the Agricultural Libraries Section in 1930, went even farther when he recommended "international cooperation of library photostats," and suggested that "A few large libraries, one or two in a country, should establish photostat bureaus to furnish copies of any paper desired, and such bureaus should be self-sustaining through a charge made sufficient for maintenance of service."

Today photoprints and microfilm are supplied on a large scale by the Library of Congress, Army Medical Library, United States Department of Agriculture Library, and by other special, academic, and public libraries. Use of the continuous roll method has made it possible for the United States Department of Agriculture Library to furnish photoprints and microfilm at very low cost to workers in universities, research institutions, and private industry. Photo- copies of items listed in the Bibliography of Agriculture may be obtained from our copying service, if not available in local libraries or from the publishers. The scientist, therefore, need not be hampered in his research because his library is not the so-called "ideally perfect library" and does not have the article he needs. The photoprint, or microfilm, is the answer and at a rate of 35,000 to 45,000 times a year in the United States Department of Agriculture Library.

A service which should be available to technical agricultural workers, and which is not generally available, is a translation service. Too many research workers are not acquainted with much of the world's literature because they do not read the language in which it is written or do not have time to read it in its original form. It is recommended that a central translation service be set up in a library which has a fairly complete collection. If this is not feasible, a decentralized service, with certain libraries responsible for translations of certain languages or subject matter, is suggested. A union catalog of translations available and in progress would then be necessary. In either case, a centralized collection of completed translations, a means of informing the agricultural world that the translations are available, and facilities for borrowing and copying translations would be needed.

It is the responsibility of the agricultural librarian, therefore, to make books and their contents available to the technical agriculturist by means of loans, reference service, card catalogs, photographic reproductions, translations, bibliographies, and indexes. His success in providing such services depends to a great extent on the availability to his library, and consequently to his clientele, of any book, article, patent, or pamphlet in the field of agriculture and the (Continued on page 33I) 
tions there has been an increase of $\$ 6.28$ per student expenditure for library purposes in the eighteen year period, and the average ratio of library to total university expenditures has increased from 2.52 to 2.77 per cent. If however, the decreased purchasing power of the dollar is considered, it seems doubtful that there has been any significant improvement.

When these averages are compared with the commonly used standards of $\$ 25.00$, now increased to $\$ 37.50$, per student and 4 to 5 per cent of the total institutional expenditures, one can have his choice of conclusions: either the library situation in most land-grant colleges is very bad; or, the standards are higher than they should be. It may be argued that setting the minimum at 4 per cent creates an objective at which institutions should continue to aim even though, if past experience is a guide, they can never expect to achieve it. On the other hand, it may be argued that landgrant colleges, which do not offer a full university program, may not require the 4 per cent ratio. It is not inconceivable that a lower expenditure per student and a lower ratio than the one that has been commonly used may serve to provide adequate library services and facilities in institutions confined to technical programs of instruction and research.

In any case, it seems clear that the two standards: per student expenditure, and ratio of library expenditures to total expenditures, should be worked out so that there is a significant relationship between them. As things now stand, if we say the per student expenditure should be $\$ 37.50$ we are in effect saying that for an institution such as Cornell a library budget of approximately $\$ 400,000.00$ will meet the minimum standards. This would mean a ratio of approximately 2.75 per cent. However, if we say, as we have been saying, that the ratio should be 4 per cent, the recommended library budget would be approximately $\$ 600,000.00$ or $\$ 57.00$ per student.

\section{Library Service to Technical Agriculturists}

\section{(Continued from page 326)}

underlying sciences whether from his own library shelves, or those of the U. S. Department of Agriculture Library, the $\mathrm{Li}$ brary of Congress, the University of California, or any other library. The technical agriculturist serves the world's oldest and most basic industry - an industry as old as the Garden of Eden. His responsibility is great. In supplying the tools with which the technical agriculturist works, the agricultural librarian also has a great responsibility. He provides the best and most upto-date material that his funds or his borrowing power can obtain; he searches the literature of the past to aid in solving the problems of the present and the future; and he does both with efficiency and dispatch, keen intelligence, and sympathetic interest. 